\title{
3.2 Roman Africa and Kinship Identity
}

"Family trees: what do they give rise too?", Juvenal asks in the first line of a satire on Roman aristocracy. ${ }^{19}$ His answer, according to one commentator, is "They grow Romans." In the last two decades the study of Roman kinship has flourished among historians, producing helpful insights on the nature of kinship identity under the empire. While early anthropologists drew from Roman history, recent Roman historians have returned to anthropological kinship theory. ${ }^{21}$ Although some Roman historians allow anthropological insights to infiltrate their practice, others impose the western understanding of kinship as something biological onto their studies. ${ }^{22}$ The following section will limit itself to a few important elements of Roman kinship, namely, the two primary kinship patterns (domus and familia), and some specific kinship ideals embedded within these kinship frameworks.

It is important to note when surveying Roman kinship that there is no Latin equivalent for the English word, "family."23 Roman historians recognize the need to explore the term familia alongside its counterpart, domus (house, household,

19 Satire 8: Stemmata quid faciunt?

20 John Henderson, Figuring out Roman Nobility, (Exeter: University of Exeter Press, 1997), 15.

21 Richard Saller, "Roman Kinship: Structure and Sentiment," in The Roman Family: Status, Sentiment, Space, ed. Beryl Rawson and Paul Weaver, (Oxford: Clarendon Press, 1997), 8; e.g. Maurizio Bettini, Anthropology and Roman Culture: Kinship. Time and Images of the Soul [Antropologia e cultura romana: Parentela, tempo, immagini dell'anima], trans. John Van Sickle, (Baltimore: Johns Hopkins University, [1988]1991). For a review of Roman kinship studies going back to Morgan, see Suzanne Dixon, The Roman Family, (Baltimore: Johns Hopkins University Press, 1992), chapter 1. See also Dixon, "Conflict in the Roman Family," in The Roman Family, ed. Rawson and Weaver, 149-167, for a review of sociological studies of the family and historians of the family. For criticism of early anthropologists' use of Roman kinship, see Geoffrey S. Nathan, The Family in Late Antiquity: The Rise of Christianity and the Endurance of Tradition, (London: Routledge, 2000), 7.

22 e.g. M. Golden, “Did the Ancients Care When Their Children Died?" G\&R 35 (1988): 159-60, who argues that the ancients did "care" because they shared the same psycho-somatic emotions as individuals today. More recently, see E. Dickey, "Literal and Extended use of Kinship Terms in Documentary Papyri," Mnemosyne 57 (2 2004), 132-3, who struggles to explain the use of kinship terminology that is "not merely exotic; they are biologically impossible." This is not to say that no Roman understood any form of kinship as biological or based on "blood." The Stoics for example invoked "nature" as the formal cause of kinship (e.g. Cicero, De officiis 1.54). Stoics, however, often tend to explain phenomenon in terms of 'nature' and, therefore, should not represent Roman conceptions of kinship at large. Although Tertullian himself could invoke "blood" imagery (e.g. Adu. Marc. 4.19.1) in matters of descent, a biological model of kinship, it is argued here, should not predetermine or limit any reading of the sources in light of anthropological theories of kinship. Matters of kinship, much like gender, were not fixed, or essentialized in the Roman context; see Huskinson, "Looking," 10-1. It should be noted, moreover, that recent Roman historians typically do emphasize the complex interconnections of kinship, economics, religion, etc., especially regarding "identity"; e.g. Shelley Hales, The Roman House and Social Identity, (CUP, 2003), 1-3.

23 Saller, Patriarchy, Property and Death in the Roman Family, (CUP, 1994), 96. 
etc.), in order to better understand Roman kinship. Both of these kinship structures are based on legal and social bonds and not, necessarily on biological consanguinity. ${ }^{24}$ The Roman familia is best understood in terms of descent and inheritance and is defined, in anthropological terms, as inclusive of all agnatic or patrilineal kin. ${ }^{25}$ Therefore, a woman would remain in her father's familia even after marriage and her children would remain in her husband's familia even after divorce. $^{26}$ The domus, on the other hand, is closer to the English term "household," in that anyone living in the estate of a dominus (lord, master, head of house, etc.) is considered kin, meaning that kinship by domus includes spouses/concubines, children, clients and slaves. ${ }^{27}$ Here, the concept of "dependents" is helpful in that a domus often includes all - things and persons under the dominus. ${ }^{28}$ On the double application of domus to both people and physical property, Nathan's assessment of two models is helpful: (1) Nathan criticizes the "legal model," wherein the domus encompasses the property of the dominus (children, slaves, goods, etc.), as too rigid and limiting; (2) he also criticizes the "sociological model," that is the domus as space consisting of a physical house and inhabited by individuals, for "confusing family with space." 29 If, as Nathan suggests, both models are inadequate, they do, nevertheless, help to underscore the physical or legal referents sometimes indicated by the term domus. $^{30}$

Although much could be said about the institutions of the domus and the familia, for present purposes their symbolic importance in Roman identity needs delineating. Gardner has argued that the familia, defined as "Roman citizens,

24 Jane F. Gardner, "Legal Stumbling-Blocks for Lower-Class Families in Rome," in The Roman Family, ed. Rawson and Weaver, 35.

25 Nathan, The Family, 30.

26 It should be noted that these are legal constructs of the familia and may not completely represent all Roman kinship networks; see below. On sine manu marriages, see Gardner and T. Wiedemann, The Roman Household: A Sourcebook, (London: Routledge, 1991), 17 and 57. This practice was especially prevalent in the Principate. Whereas, in the Republic, more marriages included the legal transfer of the daughter/wife from the father's familia to the husband's familia.

27 Dixon, The Roman Family, 4. For time when domus and familia can "shade into one another" in legal terminology, see Saller, Patriarchy, 86-7; however, Dixon, The Roman Family, 4, draws on the consensus of scholars who read the domus as the nuclear family in general usage. Similarly, see the definition of Gardner and Weidemann, The Roman Household, 3. On slaves as kin, see Dixon, The Roman Family, 2; Dale B. Martin, "Slave Families and Slaves in Families," in Early Christian Families in Context: An Interdisciplinary Dialogue, ed. David L. Balch and Carolyn Osiek, (Cambridge: William B. Eerdmans Publishing Company, 2003), 207-30; and Nathan, The Family, 32-3. Similarly, on clients as kin, see Gardner and Wiedemann, The Roman Household, 43-5; and Saller, "Patronage and Friendship in Early Imperial Rome: Drawing the Distinction," in Patronage in Ancient Society, ed. A. WallaceHadrill (London and New York, 1989), 49-62, who discusses the many aspects of the "relationships," including numerous North African examples.

28 Saller, Patriarchy, 81; or, less often, under the domina (lady, mistress, head of house, etc.)

29 Nathan, The Family, 8.

30 Saller, Patriarchy, 80. 
joined in lawful matrimony and producing legitimate children, and (usually) with some property to transmit by inheritance," served to perpetuate the status quo of the upper classes. ${ }^{31}$ Moreover, the legal use of familia, and often the common parlance, represented one's status in society in the sense of being "well-born" - a phenomenon of great importance to many Romans. ${ }^{32}$ Regarding the domus, Saller notes that one could have multiple domi (in the sense of physical places of residence), or, alternately stated, multiple places of residence could fall under one dominus and technically be considered his domus, and he suggests that the primary home "might be distinguished from his other houses by a sacred quality (the lar) and a practical managerial function (the account books)."33 Saller further elaborates on how "the sacred quality of the domus made it an especially emotive symbol for generals to employ in appeals to their soldiers. ...Romans were called on to fight for patria domusque." 34 The symbolism of the domus is also important in terms of one's identity and place in society: "In terms of their perception of their place in the world, [Romans] symbolized their leading position in society, not by representing themselves as head of a clan or family - Roman kinship relations were not hierarchical in this sense - but by representing themselves as lords (domini) of wealthy and powerful houses (domus)." ${ }^{, 35}$ Both the domus and the familia, therefore, represent aspects of Roman kinship and symbolize status and wealth.

Romans valued several other ideals in their construction of kinship and kinship identity, including the authority of the father, the importance of pious heirs and the hierarchical symbolism of the domus. In the legal and literary sources, the pater/paterfamilias/dominus held absolute authority over his dependents, and his right over children, patria potestas, is depicted as including even the right to take their life. ${ }^{36}$ Women on the other hand, especially women as

31 Gardner, "Legal Stumbling-Blocks," 36. On the connection between class and kinship, see Dixon, The Roman Family, 11; Nathan, The Family, 3 and 27; and Weaver, "Children of Junian Latins," in The Roman Family, ed. Rawson and Weaver, 55-72. On the kinship of slaves, see M.B. Flory, "Family in familia: Kinship and Community in Slavery," $A J A H 3$ (1978) 89, who says, "Within slave society the terms 'conseruus' and 'collibertus' undoubtedly had all the force of kinship designations."

32 Gardner, "Legal Stumbling-Blocks," 35.

33 Patriarchy, 81; for more on the religious and economic aspects of the domus, see below. Saller also notes (94) how one can "...diminish the honor of the household. In the choice of a new Vestal Virgin in AD 19 Fonteius Agrippa's daughter was passed over through no fault of her own: 'For Agrippa had diminished his house by divorce' (nam Agrippa discidio domum imminuerat, Tacitus Annals 2.86). Of course, divorce was common at this time, and it was frowned on only in special situations where religious purity was required."

34 Ibid, 90; ref. Tacitus Historiae 1.29; and Silius Italicus 16.593, where in defeating the Carthaginians, Scipio was said to be taking revenge for patria and domus; and Virgil, Aeneid 7.122, who has Aeneas exclaim upon landing in Italy, 'Hic domus, hae patria est.'

35 Saller, "Roman Kinship," 29.

36 Gardner and Wiedemann, The Roman Household, 5. Past understandings of a strict paterfamilias with absolute authority have been challenged: Dixon, The Roman Family, 45-8; Dixon "Conflict," 152; Saller, Patriarchy; a consensus of scholars now understand the 
wives, were not highly valued, as seen in the high rate of divorce and remarriage, but they were deemed important in producing heirs for their husbands. ${ }^{37}$ While some valued the practice of uniuira (life-long allegiance to one spouse, even after the spouse's death) during the Republic, the ideal had all but disappeared by Tertullian's day, especially under the Augustan laws penalizing celibacy. ${ }^{38}$ Children, as both heirs and status symbols, were expected to uphold pietas (duty or respect) in relation to their pater, a value propagandized in the AnchisesAeneas-Ascanius model. ${ }^{39}$ These values formed an image of the home as a microcosm of larger society, wherein the patron/client roles extended to everyone within the empire. ${ }^{40}$ The correlation between the household religion and the imperial cult: each member of the household is expected to honour the genius of the dominus, as the empire at large is expected to do the same for the emperor. ${ }^{41}$

Since Roman historians know practically nothing about the kinship practices of the lower classes in Rome and Italy, it is no surprise that the same can be said of Carthage and Africa Proconsularis. In reference to areas outside of the Roman center of power - namely the areas of Spain and Gaul, Nathan asserts, "native systems of family and community may well have endured or even prevailed." In reference to the relatively late periods of the empire, Jonathan Barlow argues

paterfamilias to have had authority over familias - parallel of dominus in the domus - and that this authority was a highly valued ideological construct of ancient Rome: Nathan, The Family, 27; and Shaw, "Raising and Killing Children: Two Roman Myths," Mnemosyne 54 (1 2001): 31-77. Moreover, scholars recognize the paterfamilias to symbolize "property owner": Gardner and Weidemann The Roman Household, 113; Saller, Patriarchy, 155; Saller, "Pater Familias, Mater Familias, and the Gendered Semantics of the Roman Household," CPh 94 (2 1999): 182-197.

37 For an overview of Roman women, see Dixon, Reading Roman Women: Sources, Genres, and Real Life, (London: Duckworth, 2000). On marriage, see Susan Treggiari, Roman Marriage: Iusti Coniges from the Time of Cicero to the Time of Ulpian, (Oxford: Clarendon Press, 1991). On divorce, see Nathan, The Family, 20-1; for debate on the "ease" of divorce, see Treggiari, "Divorce Roman Style: How Easy and Frequent was it?" in Marriage, Divorce and Children in Ancient Rome, ed. Rawson, (Oxford, 1991), 31-46.

38 On this ideal, see Gardner and Wiedemann, The Roman Household, 57; and Nathan, The Family, 22 n. 60, "An Ideal espoused by the imperial poets." On "Augustan," see Saller, Patriarchy, 1; however, Dixon, The Roman Family, 160-1, argues that only legal changes took place, not "significant" societal shifts. Also see I.C. Mantle, "The Roles of Children in Roman Religion," $G \& R 49$ (1 2002), 105, for the ideal of uniuira remaining in the offices of religious cults because uniuira symbolized one's purity.

39 Dixon, The Roman Family, 22; cf. Seneca, De consolatione ad Marciam 26.2, who says one should hand on the domus "in an undiminished state" [in integro statu]; Tacitus Annals 4.1, 6.46; and Suetonius, Caligula 13. On pietas, see Saller, Patriarchy, 105-9. On "Anchises-," see Rawson, "The Iconography of Roman Childhood," in The Roman Family, ed. Rawson and Weaver, 205-232.

40 Dixon, The Roman Family, 24-5; and Saller, Patriarchy, 102;

41 Christopher P. Jones, Kinship Diplomacy in the Ancient World, (HUP, 1999), 84; Gardner and Weidemann, The Roman Household, 31 and 124; Mantle, "The Roles," 7; Hans-Friedrich Mueller, "Vita, Pudicitia, Libertas: Juno, Gender, and Religious Politics in Valerius Maximus," TAPA 128 (1998), 234; Nathan, The Family, 26; and Saller, Patriarchy, 89;

42 The Family, 7. 
against the notion that the Franks' "kinship structures break up as a result of Romanisation," maintaining that Franks kept close ties to kin regardless of whether kin were inside or outside of the empire. ${ }^{43}$ Barlow, moreover, views the kinship networks of Gauls and Germans within the broader discourse on identity, asserting that such peoples would hold a "multicultural identity." 44 Even within certain provinces kinship structures would have varied widely, as in Egypt where urban and rural households differed. ${ }^{45}$ The variations in kinship throughout the empire is reflected in North Africa as well.

Although the problem of scant sources remains for the topic of indigenous kinship structures in North Africa, scholars like David Cherry rely on archaeology to unearth relevant data. Cherry finds Libyan society patriarchal and believes that marriage was generally polygamous, although the Punicizing influence of Carthage removed polygamy from the surrounding rural areas. ${ }^{46}$ Cherry proceeds to link the kinship structure of indigenous North Africans with the overall organization of society around local elders, which extended to broader clan networks; he limits "chiefdoms" and "kingdoms" to the western region of Numidia which were largely established by the influence of Rome. As Rome colonized North Africa, the new elites who rose in status from the indigenous population and assimilated Roman kinship ideals. ${ }^{47}$

As with so many new elites from the provinces, Africans rising into the ranks of the equestrian and senatorial classes often kept kinship ties and even primary residences in their patria. Although Senators were required to take up residence in Rome, many provincials of senatorial rank kept their focus on home estates, as summed up by Trajan, who said that Rome was seen by many senators "non pro patria, sed pro hospitio aut stabulo." 48 Werner Eck comments on this passage and this phenomenon, explaining that new elites' patria symbolized a family's history and identity. ${ }^{49}$

Extant accounts of African new elites indicate that many individuals assimilated kinship practices and ideals of Romans in order to help improve their

43 "Kinship, Identity and Fourth-Century Franks," Historia 45 (2 1996), 223.

44 Ibid

45 Saller, Patriarchy, 4.

46 Frontier, 20; ref. Herodotus, 4.172, and Sallust, Bellum Iugurthinum 80, and J.A. Ilevbare, "Family and Women in North Africa from the Fifth to the First Century B.C.." Nigeria and the Classics, 10 (1967-8), 36; cf. Cherry, "Marriage," 71-83, where he finds the marriages between "Roman(ized) and un-Romanized" uncommon.

47 Cherry, Frontier, 102-3, notes, "There is, however, no evidence, of any kind, to show that soldiers (or the Roman civilians who took up residence in the frontier-zones) routinely married indigenous women (in North Africa or in any of the other provinces). The marriage-patterns attested on the surviving epitaphs of the Algerian frontier-zone, which are examined below, would seem to indicate that the opposite is more likely to have been true - few of the soldiers or Roman(ized) civilians who are attested appear to have married indigenous women."

48 Pliny 6.19.4, cited/trans. in Eck, "Rome and the Outside World: Senatorial Families and the World They Lived In," in The Roman Family, ed. Rawson and Weaver, 7.

49 Eck, "Rome," 73-99. 
status in society. Both Fronto and Apuleius invoked hospitii iura (the rights of friends) in terms of kinship in order to further themselves and fellow Africans in Roman society. ${ }^{50}$ As someone wishing to leave an estate to his familia, according to Saller, Fronto mourned the loss of his first five children. ${ }^{51}$ Both Apuleius and a supposed African and former slave, Publius Terentius Afer (or "Terence the African"; c.195-159 BCE), employ Roman imagery from the Roman wedding in their writings, although this would be natural when writing for a Roman audience. $^{52}$ The more prominent aspect of new elites' assimilation of Roman kinship is found in reference to the domus. ${ }^{53}$

The domus as a symbol of status and wealth was highly valued by many new elites in Africa. ${ }^{54}$ Dixon understands Apuleius" "defense" as primarily regarding the accusation of opportunistic marriage made by his new stepson: "...the stereotype of the scheming stepfather is the core of the case which he must demolish." 55 This understanding of Apuleius' strategy, Saller observes, explains where he returns the accusation on the stepson, whose domus is said to be "drained and full of children" (exhausta et plena liberis). ${ }^{56}$ Apuleius, like many new elites, subsumed the Roman understanding of the domus as patrimony of the familia. Another example of the domus as symbolic of Romanization of African new elite is in the "Mactar Harvester." T7 This new elite's information is known by the inscription in his honor, and Saller describes how he began without domus and had an "insignificant father" (paruus parens) but worked to earn "a domus

50 Gardner and Weidemann, The Roman Household, 176; ref. Fronto, De nepote amisso 1.3 and Apuleius, Apologia 94f.

51 Patriarchy, 9; ref. De nepote amisso 2.1-2; and Ad amicos 1.12, where Fronto wrote to his sonin-law Aufidius Victorinus, legate of Germany early in Marcus Aurelius' reign, that with the favor of the gods nostra familia would be increased "by children and grandchildren" [liberis ac nepotibus]. On this last quote, Saller notes that it is one of only three times that familia refers to cognate kin. Another being Apuleius, Metamorphoses 5.28 who included Cupid in the familia of Venus. The last occasion is a "carelessly" presented example by Suetonius, who elsewhere only used familia agnatically. Unfortunately, no one has explored these African new elites' alternate usage of familia.

52 On Terence, see Katerina Philippides, "Terence's Eunuchus: Elements of the Marriage Ritual in the Rape Scene," Mnemosyne 48 (3 1995): 272-84; on Apuleius, see Sophia Papaioannou, "Charite's Rape, Psyche on the Rock and the Parallel Function of Marriage in Apuleius' Metamorphoses," Mnemosyne 51 (3 1998): 302-324, who interprets the scene of Charite's rape - and thereby the whole Metamorphoses - in light of the Roman wedding rituals; however, Donald Lateiner, "Marriage and the Return of Spouses in Apuleius' Metamorphoses," Classical Journal 95 (4 2000): 313-332, believes the overarching story turns the attention away from religious rituals and ceremonies and focuses on the "redirection of an entire life from sexual promiscuity into social isolation" (330). For Septimius Severus on marriage laws, see Saller, Patriarchy, 118.

53 Hales, The Roman House, 7, 167-72.

54 Ibid, 171, 195-204.

55 "Conflict," 163; for more on the step-father, see Dixon, "Conflict," 155.

56 Patriarchy, 86; ref. Apologia 76.

57 An inscription discussed by M.I. Rostovtezeff, Social and Economic History of the Roman Empire, 2nd ed., (Oxford, 1957), 331; and taken up by Saller, Patriarchy, 88. 
that lacked nothing" (nullis opibus indiget ipsa domus). ${ }^{58}$ The emphasis of the inscription, according to Saller, is his domus which signified his status, which in turn provided him with upward mobility in Roman society. New elites represent individuals with kinship networks bound up in indigenous society, but with kinship ideals reflective of Roman colonizers, ideals which emphasized the economic ramifications of the familia and the domus, a topic discussed further under the heading of class theory. ${ }^{59}$

\subsection{Ancient African Christians and Kinship Identity}

Few scholars have examined the North African Christians in terms of kinship, a fact largely due to the lack of extensive sources. ${ }^{60}$ One exception is Michael Penn's use of performance theory to examine the ritual of kissing among early Christians, including those in North Africa. ${ }^{61}$ Penn finds that Christians incorporated the kiss on the lips, an act performed between kin, in order to realign the group boundaries of its members, as shown by the many examples of converts who refused to kiss members of their own domus or familia after receiving the "kiss of peace." 62 When examining the sources from North Africa, Penn notes that the familial kiss among Christians crossed class boundaries, as when Perpetua, "well-born" (honeste nata, PSPF 2.2) kisses other martyrs who are slaves. ${ }^{63}$ This analysis of North African Christian practices in terms of kinship is one example of the insights gained from this approach.

The Passio sanctorum Scillitanorum preserves little information on any level, including that of kinship. A more complex understanding of kinship which includes economic and religious aspects, however, assists in interpreting the account of the first known martyrs in Africa. The proconsul presiding over the

58 Patriarchy, 88.

59 See section 2.3.4.

60 See for example, the study on North African Christian marriages by David G. Hunter, "Augustine and the Making of Marriage in Roman North Africa," JECS 11 (1 2003): 63-8, who finds no specifically Christian form of marriage in North Africa from Tertullian through the time of Augustine. For studies of early Christian kinship, see Halvor Moxnes, ed., Constructing Early Christian Families: Family as Social Reality and Metaphor, (London: Routledge, 1997), incorporating anthropological theory; and Balch and Osiek, eds., Early Christian Families, a dialogue of Christian origins and Roman scholars. For women's roles in early Christian communities, see MacDonald, Early Christian Women, who employs anthropological theory.

61 "Performing Family: Ritual Kissing and the Construction of Early Christian Kinship," JECS 10 (2 2002): 151-174. See also Penn's full treatment of this subject: Kissing Christians: Ritual and Community in the Late Ancient Church, (Philadelphia: University of Philadelphia Press, 2005).

62 Lucy Grig, Making Martyrs in Late Antiquity, (London: Duckworth, 2004), 21 n.95, comments more generally on the imagery of "a world turned upside-down."

63 "Performing Family," 162; ref. PSPF 21.7. For the slave designation as ambiguous, see Trevett, Montanism, 181; and Tabbernee, Montanist Inscriptions, 111 . However, most scholars accept the slave status of the martyrs; e.g. Dunn, Tertullian, 16. 